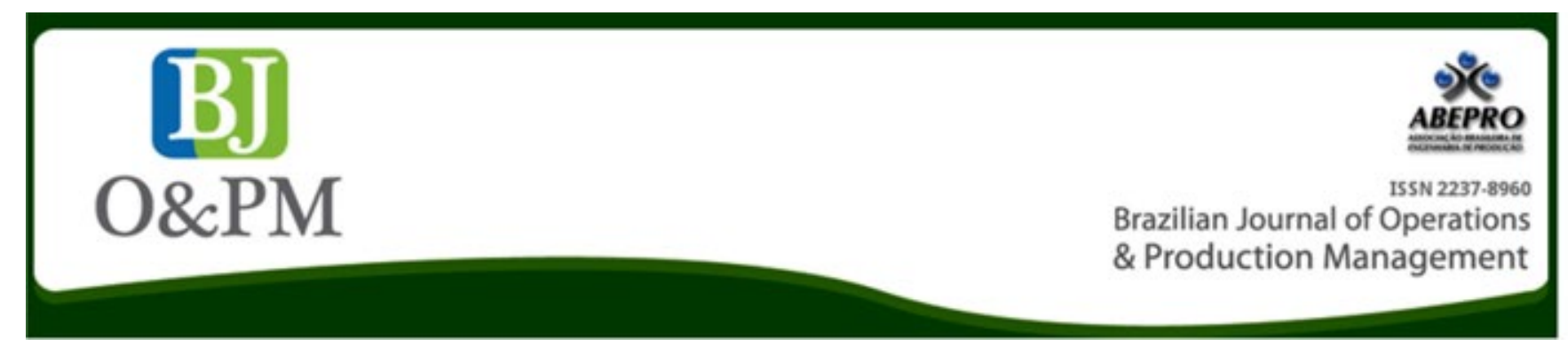

\title{
ERP IMPLEMENTATION PROJECT IN A BREWING MANUFACTURER: THE QUALITY ATTRIBUTE AS A PERFORMANCE DIFFERENTIAL
}

\section{Alaercio Nicoletti Junior alaercionicoletti@hotmail.com Methodist University of Piracicaba - UNIMEP, Piracicaba, São Paulo, Brazil}

\section{Mauro Luiz Martens}

mauro.martens@gmail.com Methodist University of Piracicaba - UNIMEP, Piracicaba, São Paulo, Brazil

\section{Maria Célia de Oliveira} mariaceliaoliveira03@gmail.com Methodist University of Piracicaba - UNIMEP; Mackenzie Presbyterian University, Piracicaba, São Paulo, Brazil

\begin{abstract}
This article aims to discuss the importance of the focus on quality attributes in an ERP system implementation project in a Brazilian brewing industry. The quality, as part of the "iron triangle" for conducting projects, can be monitored and associated with the project performance from the indicators associated to the quality attributes. The case study covered an Enterprise Resources Planning (ERP) system implementation on 6 business units of a brewing manufacturer distributed in different regions of Brazil, followed for eighteen months and it involved interviews with stakeholders, analysis of routines and documents, and people observation. The success of the project could be attributed to the performance indicators by meeting the design assumptions and the perception of the teams and project managers.
\end{abstract}

Keywords: Information System; Project Management; Quality in Project; Iron Triangle; Brewing. 


\section{INTRODUCTION}

Identify critical factors for the implementation of ERP (Enterprise Resources Planning) systems has been the subject of most of the studies on ERP (RAM et al., 2014). Authors such as Dezdar and Ainin (2011) and Schniederjans and Yadav (2013) raised in their studies the project management as one of the critical success factors for the implementation of an ERP System project. According to the Project Management Institute - PMI (2013), project management is related to the application of knowledge, skills, tools and techniques to obtain benefits in projects; these, in turn, are temporary initiatives with defined start and end, with the goal of creating a product, service or result. In this sense, according to Ahmadi et al. (2015), the successful implementation of an ERP system project is a result on how the organization manages the relevant preparation activities, and is critical in terms of the role of project management practices in ERP implementation projects (Badewi, 2016).

Therefore, considering the project management, Basu (2014) associates the success of projects to the three criteria, known as the iron triangle: "quality, cost, and time", with the first two being easily defined and measured while the quality is more subjective. Even according to Basu (2014), subjectivity around quality is often the source of disputes in the projects, since many times the designs meet the other items of the iron triangle (cost and time) and the client is not satisfied with the delivery of the project. In addition, Shenhar and Dvir (2007), declare that indicators of cost, time and scope (quality) can contribute to improving the efficiency and results of the projects, and may provide direct benefits to the organization, design team, as well as to the customers of the organization.

This paper will discuss the role of quality in project management, considering the cost, time and quality triangle (scope), confirming the importance of the quality perspective to achieve the other two (cost and time). The study will be developed in six productive BUs of a brewing manufacturer, identifying performance indicators defined by the management and implementation of the project and the accompanying during implementation. The results are evidenced from defined indicators for the monitoring of the criteria quality, cost, and time (iron triangle), namely, percentage of legacy systems (quality dimension), percentage of rework (process dimension) and customization of the solution (time dimension).

The main research question of this study is to identify whether the achievement of the quality perspective of the iron triangle contributes to the achievement of the other two perspectives (cost and time). The paper is divided into six sections. First, a review of literature addresses the attention to ERP systems and its implementation, project management and quality as knowledge area of project management for ERP Systems implementation. The third section deals with the research method, the longitudinal case study approach and its steps. In the section four, named results, the studied company case application is presented. The fifth section performs the discussions of the case study results. The conclusion presents the contributions of the study, its limitations, and suggestions for future studies.

\section{LITERATURE REVIEW}

This study draws upon the theory of three topics: ERP system and its implementation, project management, and quality as the knowledge area of project management.

\subsection{ERP System and its implementation}

ERP is a company information system that integrates and optimizes business processes and transactions of a Corporation (Moon, 2007). Amalnick (2011) highlights that ERP systems are software packages that integrate business processes, such as manufacturing, planning, sales, finance, human resources, budgeting, and customer services. Yeh and $\mathrm{Xu}$ (2013) complement it by stating that the ERP system integrates all data flows and business processes in the organization. A successful implementation of an ERP system depends on how an organization manages the availability of relevant activities to achieve an adequate level of preparation for the ERP implementation (Ahmadi et al., 2015).

Plaza (2016) handles the implementation of ERP system projects as complex projects of information technology (IT), with thousands of implementations worldwide, and these projects feature length between 6 to 24 months. Only one in six projects are delivered on time and within budget, and success are considered just $30 \%$ of the implementations (Plaza, 2016). Dezdar and Ainin (2011) raise and show the project management as one of the success factors for the implementation of an ERP System. Bernroider et al. (2014) also associated the ERP implementation with the increase of the business capabilities of companies, confirming that a better project performance is associated with a better development of ERP empowering business capabilities.

\subsection{Project management}

The PMI (2013) defines project as a temporary effort, undertaken for the creation of a product, service or result. Several authors associate the success of projects to focus on the "iron triangle" of time, cost, and scope/quality (Shenhar and Dvir, 2007). The systematic method involves project management, tools and models, and is seen as the sequen- 
tial application of structured processes in order to institutionalize standards practices (Carvalho et al., 2015). Several authors as Dezdar and Ainin (2011), Schniederjans and Yadav (2013) and Ram et al. (2014) include, among others, the project management as a critical success factor for the implementation of an ERP system. Spalek (2015) confirmed that companies need to increase project management efficacy taking into account different perspectives as methods and tools, comprising the quality as well.

In this sense, Kerzner (1999) established five levels of skills development for excellence in project management, as follows: (i) Common Language, when the organization recognizes how a management methodology can be useful for the project's success; (ii) common Processes, when the organization recognizes the need to establish common processes of projects; (iii) unique Methodology, when the Organization recognizes the synergy of methodologies for project management; (iv) Benchmarking, when the organization compares their project management practices with competitors; (v) continuous improvement, deals with the continuous improvement of project management from the implementation of the changes identified by the benchmarking.

Mitigating the impact of risks on the project performance presents a significant challenge for the stakeholders (Jackson et al., 2016) and one way to reduce these risks is with the quality management of the project. When a project is associated with more risk (uncertainty), incentives by means of performance measures should be structured (Kornish and Hutchison-Krupat, 2017), and the quality allows these metrics of measure.

\subsection{Quality perspective for ERP Systems implementation}

A good quality management is considered a pre-requisite to superior productivity (Jacobs et al., 2017) and its concepts are fully applied to projects. Zhang and Xia (2013) confirmed in their study that a quality management system is still related to better business performance, even in today's competitive scenario. According to PMI (2013), quality is an important area of knowledge in project management, among other nine areas presented in the PMBOK. Considered as a risk of the management process (Lee et al., 2010), Dezdar and Ainin (2009) confirm the quality system of the company as a factor of success for the implementation of an ERP system.

In the same sense, Volden and Samset (2017) define quality assurance review of project documentations as one of the common characteristic of governance in projects. According to Millhollan and Kaarst-Brown (2016), quality is directly associated to the project management success as one of the metrics that allows to project manager and oth- er stakeholders to determine whether the project has been completed according to plan.

A study carried out by Basu (2014), which investigated the key role of quality in project management, considers quality as the service expectations of the client and presents a model with three dimensions of quality, as shown in Figure 1.

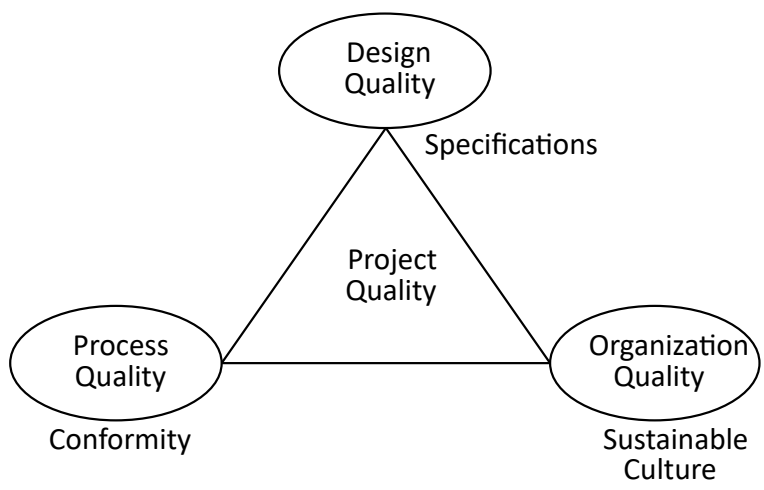

Figure 1. Three dimensions of quality (Basu, 2014).

Quality in projects, as shown in the figure, can be defined as a set of attributes, numerical specifications (quality of the design and process) and perceived dimensions (quality of the Organization). The last being determined by functional and holistic role that quality plays in the Organization, observed from high commitment dimensions such as management and knowledge of the use of tools and techniques associated to the quality (Basu, 2014). Authors as Schoenherr et al. (2017) considered the project quality performance as an opportunity of study, because of the lack of publications on the topic.

As to the quality of the process, Gonçalves (2000) highlights that companies work in processes, a process is any activity or set of activities that takes an input, adds value to it, and provides output to a specific customer. The process approach allows dismembering a complex activity in simple components and describes its elements, their support routines and the factors that influence these components (Maheshwari et al., 2010). Mahmoodzadeck et al. (2009) claim that the standardization of processes with metric definitions and common languages enables organizations in the integrity of business rules, processes and data logic. Such an approach, as that of Filipowska et al. (2009), enables the integration of process management and information technology, with the use of methods, techniques and modeling tools involving the interaction between humans, organization, applications, documents and other sources of information. Geraldi et al. (2011) identify quality attributes associated with the process, as shown in Figure 2.

The Figure 2 shows the attributes as a process with inputs and outputs, considering the tension between investigative 


\begin{tabular}{|c|c|c|c|}
\hline & INPUT & PROCESS & OUTPUT \\
\hline Explore & $\begin{array}{l}\text { - Commitment to quality } \\
\text { - Enabling capabilities }\end{array}$ & $\begin{array}{l}\text { - Integration } \\
\text { - Adaptability }\end{array}$ & - Value-adding \\
\hline Exploit & - Completeness and clarity & - Compliance & - Meet requirements \\
\hline
\end{tabular}

Figure 2. Quality Attributes Geraldi et al. (2011).

and exploratory attributes (Geraldi et al., 2011). This model includes in sequence the attributes shown in Figure 1, where the requirements treat the dimension of the quality of design; the conformity is associated to the dimension of process quality and the completeness is associated to the dimension of the organization quality.

Complementing the information about quality in the projects, Table 1 shows how some authors have conducted their studies regarding the dimensions of quality to items of the iron triangle and the performance of the project.

The Table 1 shows that the authors involve performance of projects studies, and many of them deal with the iron triangle (quality-cost-term) implicitly or explicitly. Regarding the dimensions of quality, there are two studies dealing with all three dimensions, meaning that most of them take up only the quality of design and quality of the process. The Table 2 presents the distribution of authors for the focus of their researches.

\section{METHOD}

The study is characterized as a case study that, as established by Yin (2010), initially involved a conceptual literature study on the key themes of this research, which surveyed the Association of the keywords "Project management"; "quality" and "ERP" in scientific basis. In the second stage, it was developed a longitudinal case study of ERP system implementation aimed to discuss the role of quality in project management, considering the cost,

Table 1. Classification of the authors ' works on the project quality.

\begin{tabular}{|c|c|c|c|c|c|c|}
\hline Author & $\begin{array}{l}\text { Iron trian- } \\
\text { gle }\end{array}$ & $\begin{array}{l}\text { Project per- } \\
\text { formance }\end{array}$ & $\begin{array}{c}\text { Drawing } \\
\text { quality }\end{array}$ & $\begin{array}{l}\text { Process } \\
\text { quality }\end{array}$ & $\begin{array}{c}\text { Organization } \\
\text { quality }\end{array}$ & Application in project \\
\hline Basu (2014) & $\mathrm{V}(*)$ & $\mathrm{v}$ & $\mathrm{v}$ & $\sqrt{ }$ & $\sqrt{ }$ & Transport \\
\hline Dezdar and Ainin (2011) & $\mathrm{V}$ & $\mathrm{V}$ & & & & Technology \\
\hline Flyvbjerg (2013) & & $\mathrm{V}$ & & & & Transport \\
\hline Geraldi et al. (2011) & $\sqrt{ }$ & $\sqrt{ }$ & $\sqrt{ }$ & $\mathrm{V}$ & $\mathrm{V}$ & Technology \\
\hline Jackson et al. (2016) & & $\sqrt{ }$ & $\mathrm{V}$ & & & Technology \\
\hline Lu and Liu (2014) & & $\mathrm{V}$ & & & & Manufacture \\
\hline Rothenberger et al. (2010) & & $\sqrt{ }$ & $\checkmark$ & $\checkmark$ & & Technology \\
\hline Tavana et al. (2014) & $\sqrt{ }$ & $\sqrt{ }$ & & & & Miscellaneous \\
\hline Williams (2016) & & $\sqrt{ }$ & $\sqrt{ }$ & & & Construction \\
\hline Williams et al. (2015) & $\sqrt{ }$ & v & $\checkmark$ & $\sqrt{ }$ & $\sqrt{ }$ & Multicultural \\
\hline
\end{tabular}

$\left.{ }^{*}\right)$ denotes the presence of the topic in the publication, although it is not explicit.

Source: the authors

Table 2. Classification of the authors' studies on the project quality

\begin{tabular}{|c|c|}
\hline Focus & Authors \\
\hline Quality in projects & Basu (2014); Flyvbjerg (2013); Geraldi et al. (2011); Jackson et al. (2016); Lu and Liu (2014); Rothen- \\
berger et al. (2010); Tavana et al. (2014); Williams et al. (2015).
\end{tabular}


time and quality triangle, in six BUs of a Brazilian brewing company.

According to Yin (2010), the exploratory analysis is one that explores situations in which the evaluated intervention does not have a clear set of results. Vrhovec et al. (2015) complements that a case study identifies the complex interaction between different stakeholders; it is a suitable way to investigate contemporary events where the environment is not controlled and; this is an appropriate way to study the implementation or development of software in the organizational environment. The present study will adopt a multiple longitudinal case study (Yin, 2010), contemplating the implementation of the ERP system in a Corporative Unit and in six production plants, between 2011 and 2016.

The data collection Protocol of the case study was prepared based on the model proposed by Cauchick Miguel (2007), presented on Table 3.

The study protocol involved, in addition to the data collection for 18 months, semi-structured interviews with project managers and people involved with the implementation team. The interviews were recorded for future use and content analysis. The various visits to each of the units that were in the deploying process favored collecting important information, since one of the authors acted directly on the ERP project management through participant observation.

For the measurement of the efficiency of the implementation of the ERP project target of this study, in addition to the term and cost indicators three quality indicators were defined, based each of these indicators of the dimensions of quality, as shown in Figure 3.
The model featured in Figure 3 integrates the models presented in figures 1 and 2; it serves as the basis for establishing the monitoring of the project success from the definition of indicators that measure such attribute. Thus, to measure and demonstrate the importance of quality in ERP projects, three indicators were defined: 1) percentage of the remaining post-implementation legacy systems (PLS), associated with the Quality Organization, including the legacy system that existed before the implementation of ERP, executing functions that have been integrated, such as invoices issuing, for example; 2) percentage of Rework in the Business Blue Print (BBP), which means the survey of business requirements (RBR), associated with the Quality Process and; 3) Customizing ERP Solution (CES), associated with the Quality Design, the first two being quantitative indicators and the last one qualitative (Nicoletti Jr. and Campos Jr., 2014).

Table 4 displays the detail of the indicators selected, associating them with the model of the Figure 3 by identifying their goals.

Concerning the pilot test execution, step 3 of the study, the model was implemented in the corporate unit and in one of the six plants. The complete study will analyze the other BUs, and the expansion of the ERP implementation for the distribution units will be evaluated in a second moment. In the data analysis, using the technique of content analysis and speech analysis, the synthesis of the data was collected in order to demonstrate that the option for managing by means of processes has brought benefits to the quality of the project for implementing the ERP System. To compose the report, step 5 of the study, there will be conducted discussions about the outputs of the study involving primarily the indicators planned previously. Finally, the final analyses were done for completion of the study.

Table 3. Stages of the case study research

\begin{tabular}{|c|c|}
\hline Step & Activity \\
\hline $\begin{array}{c}\text { 1. Translate conceptual-theoretical } \\
\text { structure }\end{array}$ & $\begin{array}{c}\text { A literature systematic review was developed, linking relevant terms for definition } \\
\text { of the study propositions. }\end{array}$ \\
\hline 2. Planning & $\begin{array}{c}\text { The choice of pilot plant and the pilot deployment planning and its expansion } \\
\text { to other units. The means for data collection, analysis, and control indicators } \\
\text { of the research were also selected. }\end{array}$ \\
\hline 3. Conducting the pilot test & Considered the implementation in pilot units (Corporative and one manufacturing unit). \\
\hline 4. Data collection and analysis & $\begin{array}{c}\text { Indicators to be monitored in the study and the interviews } \\
\text { for the qualitative and quantitative data were identified. }\end{array}$ \\
\hline 5. Report & $\begin{array}{r}\text { The report was held to discuss the outputs of the project, } \\
\text { interviews and quantitative indicators. }\end{array}$ \\
\hline
\end{tabular}




\begin{tabular}{|c|c|}
\cline { 2 - 2 } \multicolumn{1}{c|}{} & $\begin{array}{c}\text { Organization quality } \\
\text { (sustainable culture) }\end{array}$ \\
\hline \multirow{2}{*}{ Explore } & - Commitment to quality \\
\cline { 2 - 2 } & - Enabling capabilities \\
\hline Exploit & - Completness and clarity \\
\hline
\end{tabular}
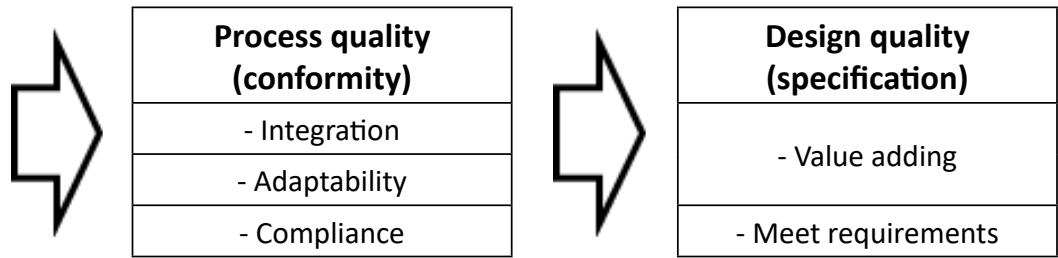

Figure 3. Dimensions of quality and their attributes. Source: the authors.

Table 4. Detail of the indicators selected for the study.

\begin{tabular}{|c|c|c|c|c|}
\hline \multirow{2}{*}{\multicolumn{2}{|c|}{ Indicator }} & \multirow{2}{*}{$\begin{array}{c}\text { Quality } \\
\text { dimension }\end{array}$} & \multicolumn{2}{|l|}{ Objective } \\
\hline & & & Descritive & Exploit \\
\hline PLS & $\begin{array}{c}\text { Percentual of } \\
\text { Legacy } \\
\text { Systems }\end{array}$ & $\begin{array}{l}\text { Organization } \\
\text { Quality }\end{array}$ & $\begin{array}{l}\text { Confirm commitment in the phases of the project, - Commitment to } \\
\text { enabling capabilities with the aim of minimizing the qualilty } \\
\text { presence of legacy systems, while preserving the - Enabling } \\
\text { integrity and quality of the solution. } \\
\text { capabilities }\end{array}$ & $\begin{array}{l}\text { Completeness } \\
\text { and clarity }\end{array}$ \\
\hline RBR & $\begin{array}{l}\text { Percentual of } \\
\text { Rework BBP }\end{array}$ & $\begin{array}{l}\text { Process } \\
\text { Quality }\end{array}$ & $\begin{array}{l}\text { Demonstrate compliance of the project from the - Integration } \\
\text { definitions in its planning. }\end{array}$ & Conformity \\
\hline CES & $\begin{array}{l}\text { Customization } \\
\text { of ERP } \\
\text { Solution }\end{array}$ & Design Quality & $\begin{array}{l}\text { Check the project requirements from the - Value-adding } \\
\text { customizations, adding value to the business }\end{array}$ & $\begin{array}{l}\text { Meet } \\
\text { requirements }\end{array}$ \\
\hline
\end{tabular}

\section{CASE STUDY}

As shown in table 3, the case study will involve five stages: (i) conceptual-theoretical definition; (ii) planning of the case; (iii) conducting pilot testing; (iv) data collection and analysis and; (v) report.

\section{Step 1 - Translate conceptual-theoretical structure}

The conceptual-theoretical survey that formed the basis for the study was presented in the Chapter 2 of this paper. In addition, below is the research contextualization with the characterization of the company and the brewing market in Brazil, which is the main focus of the company.

The company under study is a brewing industry made up of a corporate unit and six BUs, which are distributed geographically in five Brazilian States. According to the Brazilian Association of Brewing - CervBrasil (2016), there are more than 50 breweries across the country and their production chain has about 12,000 suppliers, employing approximately 8 million professionals in various areas ( 1.7 million directly), with more than 1.2 million points of sale in 5,570 municipalities in Brazil. According to the data from CervBrasil (2016), Brewer accounts for $1.7 \%$ of the Brazilian Gross Domestic Product (GDP). According to the Nielsen Institute, to remain competitive in a market, in which four companies represent more than $90 \%$ of the national production and $0.1 \%$ mar- ket share corresponds to the actual annual billing of USD $25,000,000$, requires a constant concern with the improved performance and to achieve this, it is necessary the adoption of robust and efficient systems for sharing data between the various areas of the company (Garden, 2014).

\section{Step 2 - Case planning}

The company under study held an evaluation of major ERP Systems solutions in mid-2011 and decided to deploy a solution leader in applications and with various applications in the food and beverage market globally. The pilot project involved 18 (eighteen) months of implementation, and in the first wave it would produce the entire ERP solution with modules for finance, controlling, materials, production, sales, quality, maintenance, projects and investments, besides shopping, planning, and management of Human Capital. These modules should be enabled for both the industry and distribution units.

The project was divided into 4 waves. In the first wave, object of this study, the solutions adopted have not been changes in relation to the initial planning. The Table 5 represents the timeline of implementation followed in the macro project.

In the preparation phase of the project, the project responsibilities are divided into three categories: (i) Informa- 


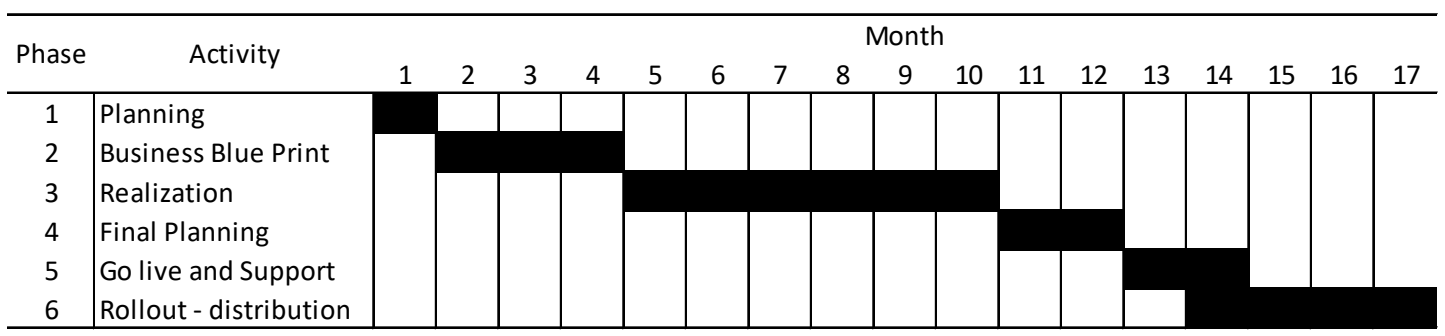

Figure 5. Macro Schedule Implementation.

tion Technology staff, responsible for managing the project and their implementation strategy; (ii) Quality Team, responsible for the identification of the value chain, processes documentation (flowcharts, procedures, etc.) and process trainings and; (iii) Business Staff, divided into twenty teams, responsible for the business areas. The project involved approximately 180 people with exclusive dedication, whereas the allocation of professionals in the project was variable during its course. In this quota, the proportion was $50 \%$ of staff and $50 \%$ of external consultants, all of whom were hired from different consulting and were managed by the company's team. ERP provider has made available a team of 15 (fifteen) people throughout the project, sharing the management of the project with the company's staff.

The governance of the project involved three follow-up committees: an internal to the project and two of the company's management studied:

(a) Committee of the project leaders, which met at least once a week, involving all business areas, IT, and processes and accompanied the implementation as a whole;

(b) Management Committee, with weekly meetings, consisting of the project management ERP implementation and the management responsible for the company's internal committees studied, namely: Human resources management; Quality management; Accounting Management; Industrial Management; and Market management;

(c) The Executive Committee, with monthly meetings, made up of the team of the Committee of managers and the Board of the company.

\section{Step 3 - Conducting the Pilot Test}

The pilot project involved 18 (eighteen) months, considering the corporate unit and one of the manufacturing BUs. The focus of the pilot was to test the implementation in one controlled scale (just one manufacturing BU) and to make possible the improvement and corrections before the expansion to the other BUs. In the integration of collaborators and external consultants to the project, training courses have been established in process mapping, business analysis and methodology for root-cause analysis in case the PDCA (Plan, Do, Check and Act) for understanding process flows, their inputs and outputs, in addition to the survey of legacy systems that would be or not maintained after the implementation of the ERP.

The project was implemented in 20 macro processes mapping, that derived 361 processes. These macro processes gave rise to the value chain of the company. A total of 44 cases (of the 361 mapped) were considered obsolete during the project, and the cases were divided into 41 BBP's. The value chain builds the 20 macro processes, which is the basis for measurement and monitoring of project performance to be monitored in data collection and analysis.

\section{Step 4 - Data Collection and Analysis}

\section{Percentage of post-implementation legacy systems (PLS)}

One of the factors that influenced the decision to return the company's ERP System studied was the amount of running Systems in the group, totaling 49 (forty-nine). Thus, the quality of the organization is evidenced by the project efficiency for ERP implementation and it can be achieved by reducing the number of legacy systems to a minimum.

The bookmark was defined by the relative percentage of the remaining post-project systems and the amount of initial systems (49). It was noted that the project was able to reduce the number of existing systems in the company, from 49 (forty-nine) to 21 (twenty-one), which corresponds to a reduction of $57 \%$ (fifty-seven percent). The functionality of the 28 discarded systems are incorporated to the ERP solution. The remaining systems basic covered functions linked to government as taxes and financial reports.

Although a statistical basis for studies on the percentage of reduction of the amount of legacy systems has not been found, the goal was achieved, since the project team, in 
Brazilian Journal of Operations \& Production Management

Volume 15, Número 4, 2018, pp. 517-527

DOI: 10.14488/BJOPM.2018.v15.n4.a5 agreement with the managers of the business areas, established, at the beginning of the project, the goal of 50\% (fifty percent) reduction of legacy systems during the first wave of the ERP implementation.

\section{Percentage of Rework in BBP (RBR)}

It measures the effectiveness of the rework of the BBP's. The indicator was given by the ratio of the percentage amount of reviews on Business Blue Print (BBP) and the amount of BBP (41), all of which were considered as those reviews that effectively constitute a change in the document of the BBP. During the first wave, it was necessary to adjust 5 BBPs (12.2\%) initially conducted, involving mappings on improvements that were considered low impact improvements in design, as the provider of the system. It was considered the achievement of this indicator, since the target set for it was $30 \%$. After the Go-live, it was held an annual routine measurement of adhesion of all BBP's in order to monitor improvements in the processes linked to the ERP.

\section{Customization of ERP Solution (CES)}

It constituted a qualitative indicator associated with the quality of the design, indicating the adherence of the solution proposed by the provider of ERP business model. This indicator was assessed qualitatively by the ERP provider, based on its implementation experiences, with the initial goal of using the standard ERP solution with a minimum of customization. According to the project management team of the ERP provider, the project was considered as of low complexity of customization, since the ABAP (Advanced Business Application Programming) developments were basically carried out for the preparation of reports. Table 6 presents the results of the three indicators evaluated post-implementation.

Table 6. Summary of the indicators.

\begin{tabular}{|c|c|c|}
\hline Bookmark & Result & Initial Goal \\
\hline 1. PLS & $57 \%$ & $50 \%$ reduction. \\
\hline 2. RBR & $12.2 \%$ & $30 \%$ \\
\hline 3. CES & Low & Average \\
\hline
\end{tabular}

It turns out that the goals outlined at the beginning of the project for the ERP System implementation were achieved, proving the quality of the project. To show a statement of an organization's Manager, collected in an interview in May (2016), about the indicators: "the monitoring of performance indicators of the project allowed guiding us in the execution and following the effectiveness of the new solution".

In interviews with other six managers directly involved in the project, including one coming from a hired consulting firm, one from a system provider, and three employees from the company under study, their satisfaction with the project could be evidenced in Table 7. At the time, answers about the 3 indicators were also collected in close-ended questions, using the Likert scale ranging from 1 (very unsatisfied) to 5 (very satisfied), according to the questionnaire of the Appendix I.

Table 7. Satisfaction survey with managers.

\begin{tabular}{|c|c|c|c|c|}
\hline \multirow{2}{*}{ Manager } & \multicolumn{3}{|c|}{ Level of satisfaction $\left({ }^{*}\right)$} & Project satisfac- \\
\cline { 2 - 4 } & Time & Cost & Quality & tionel $(*)$ \\
\hline IT & 5 & 4 & 5 & 5 \\
\hline Quality & 5 & 3 & 5 & 4 \\
\hline Administrative & 5 & 4 & 5 & 5 \\
\hline Project Manager & 5 & 3 & 5 & 5 \\
\hline $\begin{array}{c}\text { Project Manager } \\
\text { of Provider }\end{array}$ & 5 & 4 & 5 & 5 \\
\hline
\end{tabular}

$\left({ }^{*}\right) 1$ - very dissatisfied; 5 - very satisfied

Table 7 shows the overall satisfaction with the project managers and the success attributed to factors such as focus on implementation, the implementation team, and proper planning. In addition, the project has met the deadline (entry in Go Live) of the first wave, and met the established budget. There has been some increase in the value initially hired of approximately $15 \%$ of the total amount due to the acquisition of a financial solution; however, a variation of up to $20 \%$ was provided for in the initial budget of the project, which is the maximum allowed value deviation for this indicator. In the report, from the Go-live of the ERP project, a team dedicated to the improvement management of the initial project, called integration team and project management in the following waves involving the new industry BUs and distribution (after the beginning of the project two new factories were encompassed to the ERP system in addition to the four initials), also ensured the maintenance of the knowledge generated in the project and its multiplication. This new team was attended by participants of the project and by some collaborators from other business areas involved in the implementation project of the ERP business specialists.

The establishment of such a team endorsed the objectives: (i) retention of the knowledge generated in ERP; (ii) maintenance of the value chain; (iii) standardized modeling of processes; (iv) standardization of the documentation of the quality management system of the company; (v) continuous improvement of the processes; (vi) risk assessment; (vii) training and development of employees of the company; and (viii) preparation of the Organization for certification of quality systems (ISO, for example). The iron triangle (quality, cost, and time) remains in all waves of implementation, ensuring compliance with the company's expectations with respect to implementations and developments. 


\section{Step 5 - Report}

The report consolidates all the collected data in the discussion.

\section{DISCUSSION}

The ERP system implementation followed the schedule initially conceived; however, the adjustments and changes did not agree with the deadline initially set. Therefore, on a methodological perspective, the study showed that the quality performance indicators allowed guiding the project in order to meet the established assumptions forming the quality, along with the cost and time, of a methodological triangulation for project management (Basu, 2014).

The quality serves as director for the conduct of the project and contributes to the success of negotiations, whether changes to scope, cost or time limit, during the project, enabling the achievement of shared goals (Lu and Liu, 2014), which are measured by customer satisfaction and the relationship of quality, allowing the monitoring of customer satisfaction in the course of the project and allowing the construction of durable relationships (Williams et al., 2015). The initial effort in planning, taking into account aspects of quality in the project, reinforced the importance of quality design not only during and at the end of the project, but also in it beginning (Geraldi et al., 2011). The definition of the responsibilities of the project and business areas (IT, quality and business fronts) made possible the active participation of quality in design, allowing the focus on quality in planning and development, which ensured the achievement of desired results (Rothenberger et al., 2010).

Validating the implications raised in the study of Dezdar and Ainin (2011), the results were confirmed with both quantitative and qualitative indicators, and also with the positive perception of managers involved in the project. The project success was confirmed with the anticipation of the implementation of the ERP System in industry units, as well as in the distribution ones and, for these, the new units from the beginning of the rollout have already initiated its activities with the new ERP. In the course of the project, factors that received special attention from the team have emerged, generating additional costs of development, although they have not compromised the time limits and without giving up the quality of the premises. It is worth highlighting the E-Social project of the Brazilian Government that generated interaction of all areas and organization systems; however, according to the opinion of the human resources manager of the company who was responsible for the E-Social costs and the duration of the implementation, it would be larger if the new ERP system was not in use. Such factors have shown, as in Carvalho and Rabechini (2015), the importance of the role of the project management to mitigate the uncertainties and risks that are inherent in complex projects as this case study. Finally, it is clearly perceived that the quality indicators influenced the other two perspectives of the iron triangle, as they allowed the efforts to align the project management conduction to the lean way, also saving time and costs.

\section{CONCLUSION}

The studied company found the success of the project management strategy, monitoring throughout the project the indicators established in the three perspectives of the iron triangle, with emphasis in quality. The indicators reflected the adherence of the implemented solution with the initial scope of the project, in line with the company's expectations.

It was noted that the focus on the quality of the project, from the establishment and monitoring of indicators, with a focus on its attributes (design, process and organization), contributed to the success of the implementation of the project, which was evidenced by the attendance at the premises of design and perception of the managers involved in the project implementation.

The focus on the quality perspective of the iron triangle also permitted the achievement of the other two perspectives (cost and time), which was the main researched question of this paper.

As a limitation, the study involves just a single case study, limiting comments to the company analyzed. Other intangible aspects, such as company culture, were not regarded as a factor of success for the implementation of the ERP System. For future research, it is recommended to study knowledge management and the process management of post-implemented ERP Systems in order to validate the conclusions of this article.

\section{REFERENCES}

Ağaoğlu, M., Yurtkoru, E.S., Ekmekçi, A. K. (2015), “The effect of ERP implementation CSFs on business performance: an empirical study on users " perception", Social and Behavioral Sciences, Vol. 210, pp. 35-42.

Ahmadi, S., Yeh, C-H., Papageorgiou, E. I., Martin, R. (2015), "An FCM-FAHP approach for managing readiness-relevant activities for ERP implementation", Computer \& Industrial Engineering, Vol. 88, pp. 501-517.

Aloini, D., Dulmin, R., Mininno, V. (2007), “Risk management in ERP project introduction: Review of the literature", Information \& Management, Vol. 44, pp. 547-567. 
Brazilian Journal of Operations \& Production Management

Volume 15, Número 4, 2018, pp. 517-527

DOI: 10.14488/BJOPM.2018.v15.n4.a5
Aloini, D., Dulmin, R., Mininno, V. (2012), "Modelling and assessing ERP project risks: the Petri Net approach", European Journal of Operational Research, Vol. 220, pp. 484-495.

Amalnick, M., Ansarinejad, A., Nargesi, S., Taheri, N. (2011), "New perspective to ERP critical success factors: priorities and causal relations under fuzzy environment", The Journal of Mathematics and Computer Science, Vol. 2, No. 1, pp. 160-170.

Badewi, A. (2016), "The impact of project management (PM) and benefits management (BM) practices on project success: Towards developing the project benefits governance framework", International Journal of Project Management, Vol. 34, pp. 761-778.

Badewi, A., Shehab, E. (2016), "The impact of organizational project management governance benefits on ERP project success: Neo-institutional theory perspective", International Journal of Project Management, Vol. 34, pp. 412-428.

Basu, R. (2014), "Managing quality in projects: An empirical study", International Journal of Project Management, Vol. 32, pp. 178-187.

Bernroider, E. W. B., Wong, C. W. Y., Lay, K-H. (2014), “From dynamic capabilities to ERP enabled business improvements: The mediating effect of the implementation project", International Journal of Project Management, Vol. 32, pp. 350-362.

Carvalho, M. M., Patah, L. A., Bido, D. N. (2015), “Project management and its effects on project success: cross-country and cross-industry comparisons", International Journal of Project Management, Vol. 33, pp. 1509-1522.

Carvalho, M. M., Rabechini JR., R. (2015), “Impact of risk management on project performance: the importance of soft skills", International Journal of Production Research, Vol. 53, No. 2, pp. 321-340.

Cauchick Miguel, P. A. (2007), “Estudo de caso na engenharia de produção: estruturação e recomendações para sua condução", Production, Vol. 17, No. 1, pp. 216-229.

Cervbrasil (2016), Brazilian Association of the Beer Industry, available at http://cervbrasil.org.br. (Accessed 29 may 2016).

Dezdar, S., Ainin, N. (2009), "Successful enterprise resource planning implementation: taxonomy of critical factors", Industrial Management \& Data Systems, Vol. 109, No. 8, pp. 10371052.

Dezdar, S., Ainin, N. (2011), “Examining ERP implementation success from the Project environment perspective", Business Process Management Journal, Vol. 17, No. 6, pp. 919-939.

Filipowska, A., Kaczmarek, M., Kowalkiewicz M., Zhou, X., Born, M. (2009), "Procedure and guidelines for evaluation of methodologies", BPM Business Process Management Journal, Vol. 15, No. 3, pp. 336-357.

Flyvbejrg, B. (2013), "Quality control and due diligence in project management: Getting decisions right by taking the outside view", International Journal of Project management, Vol. 31, pp. 760-774.

Garden, I. (2014), Extra foam Published in <http://veja. abril.com.br/blog/radar-on-line/economia/as-micromovimentacoes-no-mercado-de-cerveja/>. Accessed on 29 may 2016.

Geraldi, J. G., Kutsch, E., Turner, N. (2011), "Towards the conceptualization of quality in information technology projects", International Journal of Project Management, Vol. 29, pp. 557-567.

Gonçalves, J. E. L. (2000), "As empresas são grandes coleções de processos", Revista de Administração de Empresas, Vol. 40, No. 1, pp. 6-9.

Jackson, S. A., Gopalakrishna-Remani, V., Mishra, R., Napier, R. (2016), "Examining the impact of design for environment and the mediating effect of quality management innovation on firm performance", International Journal of Production Economics, Vol. 173, pp. 142-152.

Jacobs, B. W., Kraude, R., Narayanan, S. (2017), “Operational Productivity, Corporate Social Performance, Financial Performance, and Risk in Manufacturing Firms", Production and Operations Management, Vol. 25, No. 12, pp. 2065-2085.

Kerzner, H. (1999), Strategic planning for project management using a project management maturity model, John Wiley \& Sons, New York.

Kornish, L. J., Hutchison-Krupat, J. (2017), "Research on Idea Generation and Selection: Implications for Management of Technology", Production and Operations Management, Vol. 26, No. 4, pp. 633-651.

Lee A. H. I., Wei, C.-S., Lee, Y.-C. (2010), "An approach for modeling the risk transformation processes", International Journal of Industrial Engineering: Theory, Applications and Practice, Vol. 17, No. 1, pp. 1-11.

Lu, W., Liu, J. (2014), "Research into the moderating effects of progress and quality performance in project dispute negotiation", International Journal of Project management, Vol. 32, pp. 654-662.

Maheshwari, B., Kumar, U., Kumar, V. (2010), "Delineating the institutionalization process: ERP go-live to effectiveness", Business Process Management Journal, Vol. 16, No. 4, pp. 744-771.

Mahmoodzadeck, E., Jalalinia, S.H., Nekui Yazdi, F. (2009), "The Business Process Outsourcing Framework Based on Business Process Management and Knowledge Management", Business Process Management Journal, Vol. 15, No. 6, pp. 845-864.

Martin, P. A. C. (2007), "Case study on production engineering: structuring and recommendations to your driving", Production and Operations Management, Vol. 17, No. 1, pp. 216-229. 
Millhollan, C., Kaarst-Brown, M. (2016), "Lessons for IT Project Manager Efficacy: A Review of the Literature Associated with Project Success", Project Management Journal, Vol. 47, No. 5, pp. 89-106.

Moon, Y. B. (2007), “Enterprise Resource Planning (ERP): a review of the literature", International Journal Management and Enterprise Development, Vol. 4, No. 3, pp. 235-264.

Nicoletti Jr., A.; Campos Jr., F. C. (2014), “ERP System Implementation with Business Process Management at Petrópolis Group", Proceedings \& abstracts, 11th International Conference on Information Systems and Technology management, São Paulo: FEA USP.

Plaza, M. (2016), "Balancing the costs of human resources on an ERP project”, Omega, Vol. 59, pp. 171-183.

Project Management Institute - PMI (2013), "A Guide to the Project Management Body of Knowledge (PMBOK ${ }^{\circledR}$ Guide)", 5th ed., Project Management Institute, Newtown Square, PA.

Ram, J., Corkindale, D., Wu, M-I. (2013), “Implementation critical success factors (CSFs) is: Do they contribute to ERP implementation success and post-implementation performance?" International Journal of Production Economics, Vol. 144, pp. 157-174.

Ram, J., Wu, M-L., Tagg, R. (2014), “Competitive advantage from ERP projects: Examining the role of key implementation drivers", International Journal of Project management, Vol. 32, pp. 663-675.

Rothenberger, M. A., Kao, Y.-C., Van Wassnhove, I. N. (2010), "Total quality in software development: An empirical study of quality drivers and benefits in Indian software projects", Information \& Management, Vol. 47, pp. 372-379.

Schniederjans D., Yadav, N. (2013), "Successful ERP implementation: an integrative model", Business Process Management Journal, Vol. 19, No. 2, pp. 364-398.

Schoenherr, T., Bendoly, E., Bachrach, D. G., Hood, A. C. (2017), "Task Interdependence Impacts on Reciprocity in IT Implementation Teams: Bringing Out the Worst in Us, or Driving Responsibility?", Production and Operations Management, Vol. 26, No. 4, pp. 667-685.
Shenhar, A., Dvir, D. (2007), Reinventing Project Management: The Diamond Approach to Successful Growth and Innovation, Harvard Business School Press.

Spalek, S. (2015), "Establishing a conceptual model for assessing project management maturity in industry companies", International Journal of Industrial Engineering: Theory, Applications and Practice, Vol. 22, No. 2, pp. 301-313.

Sudhaman, P., Thangavel, C. (2015), "Efficiency analysis of ERP projects-software quality perspective", International Journal of Project Management, Vol. 33, pp. 961-970.

Tavana, M., Abtahi, A. R., Khalili-Damghani, K. (2014), "The new multi-mode model for solving multi-objective preemptive time-cost-quality trade-off project scheduling problems", Expert Systems with Applications, Vol. 41, pp. 1830-1846.

Volden, G. H., Samset, K. (2017), “Governance of Major Public Investment Projects - Principles and Practices in Six Countries", Project Management Journal, Vol. 48, No. 3, pp. 90-108.

Vrhovec, S. L. R., Hovelja, T., Vavpotič, D., Krisper, M. (2015), "Diagnosing organizational risks in software projects: Stakeholder resistance", International Journal of Project Management, Vol. 33, pp. 1262-1273.

Williams, P., Ashill, N. J., Naumann, E., Jackson, E. (2015), "Relationship quality and satisfaction: Customer-perceived success factors for on-time projects", International Journal of Project Management, Vol. 33, pp. 1836-1850.

Williams, T. (2016), "Identifying Success Factors in Construction Projects: A Case Study", Project Management Journal, Vol. 47, No. 1, pp. 97-112.

Yeh, C-H., Xu, Y. (2013), "Managing critical success strategies for an enterprise resource planning project", European Journal of Operational Research, Vol. 230, pp. 604-614.

Yin, R. K. (2010), Case study: planning and methods, 4th Edition, Bookman, New York.

Zhang, G. P., Xia, Y. (2013), Does Quality Still Pay? A Reexamination of the Relationship Between Effective Quality Management and Firm Performance.

Received: 13 Jun 2018

Approved: 08 Aug 2018

DOI: 10.14488/BJOPM.2018.v15.n4.a5

How to cite: Nicoletti Junior, A.; Martens, M. L.; Oliveira, M. C. (2018), “ERP implementation project in a brewing manufacturer: the quality attribute as a performance differrential”, Brazilian Journal of Operations \& Production Management, Vol. 15, No. 4, pp. 517-527, available from: https://bjopm.emnuvens.com.br/bjopm/article/ view/509 (access year month day). 